\title{
A multicultural experience
}

\section{Community college students create a library in a Mexican village}

\author{
by Laurie S. Linsley
}

$\mathrm{S}$ eminole Community College (SCC) has had a Mexican Studies Program for almost ten years. Students register for courses in anthropology, art, biology, nursing, or physical geography. In addition to this course work while in Mexico, students are placed at nonpaid worksites selected to fit their majors. Students have worked in health clinics, national parks, art coops, and at archaeological sites. Students have also taught English.

\section{The library component}

I had been taking Spanish for a couple of years and had come to the realization that to increase my language skills, I needed to live among Spanishspeaking people for a period of time. I discussed my interest in participating in SCC's Mexican Studies Program with Profes-

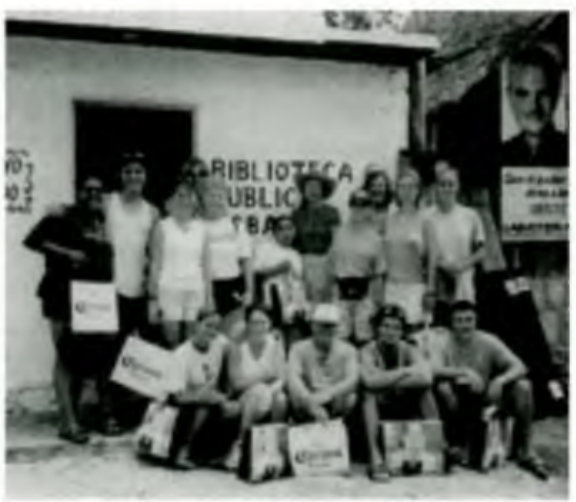

The new library in Cobá, Mexico, and the SCC students (and two faculty) who made it happen. tion. Noone said: Sure, join our group and you can build a library! My response was: Oh yes, that would be a great experience (gulp).

For the first three weeks of the summer semester, term IIIA 2000, a new concept was introduced, the library component of SCC's Mexican Studies Program: create a library in the ancient Mayan pueblo of Cobá, in the state of Quintana Roo, in the Yucatán peninsula of Mexico.

I had no experience in creating a library or even in working in a public library in the states, but I thought that with almost 30 years as a librarian, I could pull this off.

Our group of 15 students registered for courses in anthropology, art, and biology. In addition to the plans for sor Kenna Noone, coordinator of the program.

I wasn't sure what I could do-I couldn't see myself working in a medical clinic-but I decided that I could make some contribu- creating a library, students signed up for other site work in Cobá: testing the drinking water, teaching English, and working in the medical clinic.

\section{About the author}

Laurie S. Linsley is head of technical services at Seminole Community College in Sanford, Florida, e-mail: linsleyl@mail.seminole.cc.fl.us 


\section{The donations}

Where would we get the books for this library, considering our small budget? We could not have created this library without the wonderful donations. With our tiny grant budget, we were able to purchase $\$ 250$ worth of books and office supplies. During the year, I put out the call in print and on electronic lists for donations of Spanish-language materials.

Our primary contributors were San Antonio Public Library, University of Miami, and Borders Books \& Music. And, of course, we couldn't have created this library without book and office supply donations

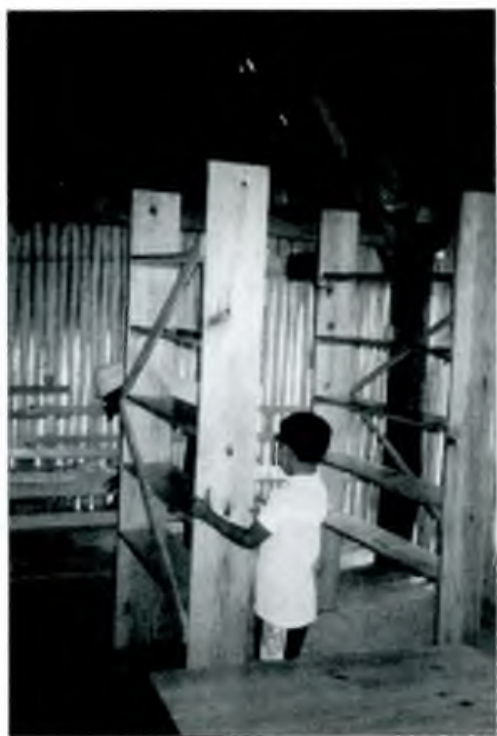

Shelves for the library were built by SCC student Mary Arseneau and the Cobá village carpenter.
I underestimated the number of books that were in those unopened, donated boxes. Because so many of the books were slender paperbacks, instead of the fewer than 1,000 books expected, we ended up with more than 1,200 books for our shelves-surprise!

When we got close to processing 1,000 books, we realized that we would run out of book pockets, date due slips, glue, and tape. A late night run was made to a small store, which sold glue and tape, and students made copies of the date due slips for current and future use. Improvisation is a wonderful thing.

from librarians and other citizens in Florida. We also were happy to accept cash donations.

During the months preceding the Mexico trip, I regularly checked local used bookstores for Spanish books and purchased them at greatly reduced rates. My happiest find was a manual typewriter that I picked up in Miami for a mere $\$ 5$.

Our most impressive contribution was solicited by Kenna Noone: Aeromexico donated 500 pounds of cargo. We put the remainder of the books in our personal checked luggage. It was a very heavy airplane and we joked that if the plane went down, only we would know why.

\section{The work}

I wish I could report that I planned for this trip all year and spent months sorting the donated books and office supplies, ordered just the right amount of library materials with our small budget, and that everything came off without a hitch. But it didn't happen that way.

I had zero time to weed and sort in advance, so rather like one who moves all the stuff from the old house to the new one, having the garage sale after the move, that is what we did. Only a few books were unusable because of poor condition or unsuitability for a small community library. We were very fortunate indeed.

\section{Reality}

We arrived thinking that we would have a building in which to create Cobá's first library. Reality set in when we heard that the building in which we were to house the books was a temporary location donated by a local group. The main principle that you learn on an adventure like this is: Be Flexible. Near the end of our time in Cobá, we learned that the governor of the state of Quintana Roo visited Cobá while we were away for the weekend and was so pleased with our work that he was having funds allocated to build a permanent building. Also, the local Villas

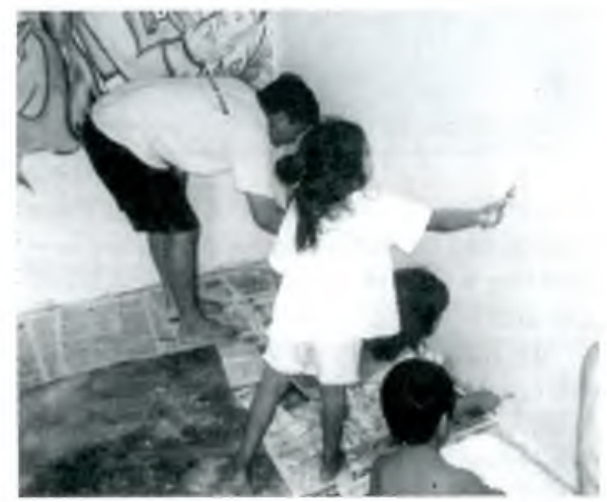

Cobá villagers painting the library. 


\section{Manual de la Operacion de la Biblioteca Pública de Cobá}

Cobá, Quintana Roo, México

1 Junio 2000

Librarian: Gertrudis Xooc May

\section{Purpose of the Biblioteca Pública de Cobá}

The Biblioteca Pública de Cobá is a gift from the Mexican Studies Program of Seminole Community College, Sanford, Florida, USA, (http://www.seminole.cc.fl.us) for the people of Cobá, Quintana Roo, México.

\section{Patrons/library users}

A. Library cards

1. Number library cards sequentially.

2. Complete a card for each community member who requests a card.

B. Registration cards

1. Prepare a registration card when each library card is issued. Put the number of the library card on the registration card and file it in the green box.

\section{Collection}

A. Reference-books do not circulate.

B. Periodicals-periodicals do not circulate.

C. General collection (remainder of the collection). Books are arranged by categories and color coded as identified on the master list. Categories are added, deleted, or changed as necessary.

\section{Lending books}

All library materials except reference and periodicals can be checked out. Procedure:

$A$. The library patron presents the library card to the librarian.

Arqueológicas hotel, where we spent three weeks, had committed to supplying the new building with a much needed air conditioning unit.

We didn't expect air conditioning, really we didn't, but we were stunned by the excessive heat and humidity, doubled by the generation of the heat (and noise) from the amazing mechanical tortilla-maker adjacent to the library. But there is an up side to every-
B. Each book in the circulating collection has a book card in the pocket in the back of the book.

C. The patron signs the book card. The librarian stamps the book card and the date due slip with the date due stamp. Books may be checked out for one week.

D. The librarian puts the book card in the green charging tray, with the cards arranged by date that the book is due.

E. If a book is overdue, the librarian contacts the patron about returning the book

F. When the patron returns the book, the librarian removes the book card from the charging tray, marks out the date due and the patron's name, and places the card in the book pocket in the back of the book.

\section{Processing books}

When a book is added to the collection:

A. Property stamp the book on the title pages and all edges.

B. Put book card, book pocket, and date due slip in the back of the book, if it is for the circulating collection.

C. Repair the book as necessary.

D. Select the category for the book and affix a spine label. Color code using the master list.

\section{The future}

As the collection expands, decisions may be made to classify the library materials according to the Dewey Decimal System and/or to create a card catalog. Guidebooks and manuals have been placed in the Biblioteca Pública de Cobá for possible future use in classifying the materials and instructions are available for preparing cards for a card catalog.

thing. It was great having a tortilla break midmorning with a six-inch stack of fresh tortillas for library workers - all for the equivalent of $\$ 1$.

The initial challenge was to build the shelves for the library. This was the main charge for my roommate Mary Arseneau, who is a carpenter for Habitat for Humanity, Inc. Mary and the Cobá minister/carpenter traveled to a nearby village to purchase the wood and the varnish for the shelves. We estimated 


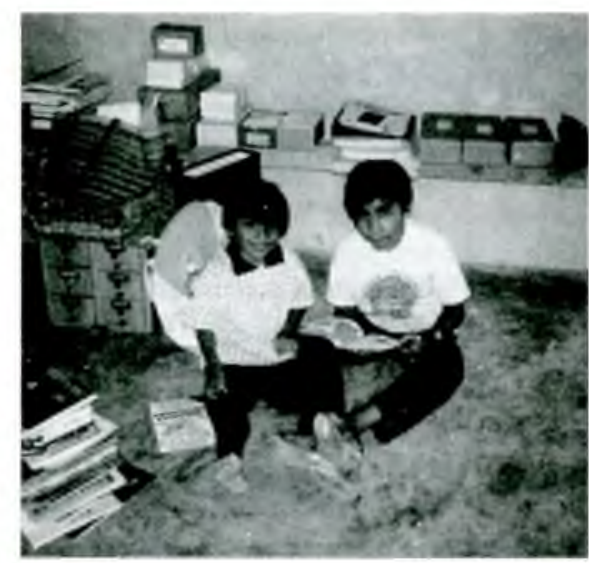

Cobá children began reading the books as soon as the boxes were opened

five sections of shelving, consisting of five shelves each, able to hold approximately 625 books (another error, as we ended up with 1,200 books). Fortunately, many of the books were small paperbacks and they easily fit on the shelves. Although I thought that the shelves were perfect, Mary was concerned that they were more narrow than shelves in U.S. libraries. But we had to go with the size of wood available at the price we could afford. Another concern was that the books would slip and slide on the shelves without bookends. This turned out not to be a problem due to the natural roughness of the wood. As you can see from the photo, the shelves worked beautifully.

We spent the first few days sorting the books, all of which were in Spanish, by broad subjects. This was a monumental task, considering that at various times, depending on who was available to work, our language skills varied from totally fluent to barely able to read Spanish. We quickly learned to rely on one another and on our Spanish-English dic-

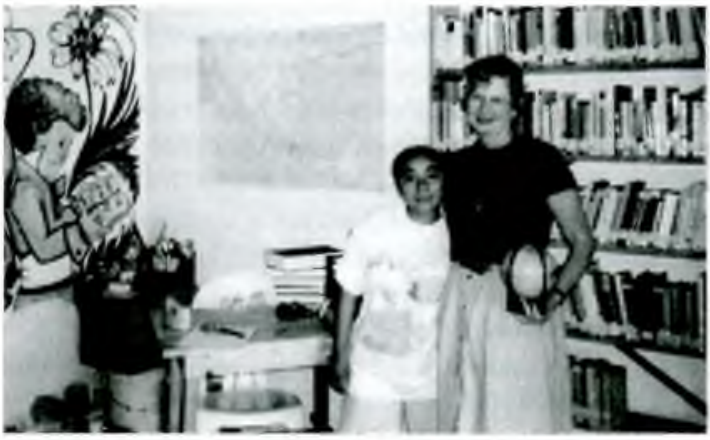

Future Cobá librarian Gertrudis May with author Laurie Linsley in the new library. on each book. Purple for Historia, green for Politica, red for Literatura, etc. We made the children's books a color easy to spot, bright yellow, and placed them on a bottom shelf. Each book was labeled with its subject and, as a simple method for arranging the books within the categories, the first letter of the author's last name, or lacking an author, the first letter of the title. This simple method worked well and the color coding made it easy to keep the books in the proper categories.

\section{The people}

By far the greatest joy in the field work of the Mexican Studies Program was the people of Mexico. We worked side-by-side with the Mexicans, rather like a mini-version of the Peace Corps. The happy result of this method of carrying out our work meant that the people of the village thought of the library as their library from the beginning. Children were in the library reading their books from the moment we unpacked them. Miraculously, they had already been taught to handle books with care and respect. Over and over we were impressed with the quiet strength and intelligence of the Mayans. We laughed together when it was discovered that few in our group were fluent in Spanish and that none of us spoke their native Mayan language. tionaries.

As we sorted books day after day, it became obvious that in three weeks we would be unable to create the planned-for card cata$\log$, nor would it be necessary in this village setting. Instead, we created broad subject categories, such as Historia, Política, and Literatura, and color-coded the subject signs on the shelves to correspond with the label 
the capital of the state of Yucatán; ruins of Chichén Itzá, Cobá, and Tulúm; seaside resorts; water activities, like floating downstream in a river and swimming in cenotes, the Yucatán version of sinkholes; and university libraries in the Yucatán peninsula.

\section{Success}

There were some materials and supplies that we hauled all the way to Mexico and never used. These included a six-drawer card cata$\log$, cards for the catalog, and Dewey Decimal schedules in English and Spanish. At first I felt guilty. In retrospect, I see that this was a good decision, and part of our capability of being flexible and working within the constraints of time and money and the present situation. A first-time village library with a full-blown card catalog and the responsibility of keeping it up when the local librarian added new materials would probably have been overwhelming. But now they have the card catalog and on our next visit, if we are able to expand the library, we may implement some of these library tools.
We finished putting together the library a day ahead of schedule. This left time for another swim and a few hours to do last minute clean up and, most importantly, to train the new Cobá librarian, Gertrudis Xooc May, who conveniently lived behind the library. Gertrudis had worked with us every day to create this new and wonderful community library in Cobá. She had also taken English classes daily from our students who taught the classes. I spent the last few hours in Cobá writing a manual of operation and training Gertrudis for her new role. Our most fluent student, Stephanie Litka, translated the manual into Spanish for Gertrudis to keep in the library.

\section{Conclusion}

My advice to you if you have a similar opportunity: Grab it, you won't be sorry. And don't worry about details. Do your best and depend on those around you.

And did I increase my Spanish language skills, which was my original goal? jSi, bablo español mucho mas!

\section{("Disappearing Reference. .. "cont. from page 694)}

2. Librarians must work with faculty to demonstrate the need for such a program. Again, the general outreach informs this process; faculty should be making the connection between the proliferation of resources and the ability of their students to maneuver in such an environment. The librarians should be able to discuss students' work with faculty in detail. This also means putting the program in the context of faculty and curriculum goals.

3. Librarians must assess the culture of their academic environment. What are student and faculty expectations? Is the campus aware of the library resources and services already provided?

4. The appointments program needs to be promoted, to both students and faculty; it's not enough to reach the motivated students. Such a program is critical to the academic success of all students.

\section{Conclusion}

There is a traditional image of Williams College that suggests the model for teaching and education on campus; it is called the Log. It's an image of the teacher on one end of a log in dialogue with a student on the other end. This rustic image handed down from more than a century ago still resonates in this technological age. The proliferation of technology and information resources gives even the smallest academic library the power of a large university. At the same time, there are unique opportunities to develop new ways to reach each student individually. The reference desk may be disappearing, but the need for research support has never been more critical.

\section{Notes}

1. Douglas Herman, "But does it work? Evaluating the Brandeis reference model," Reference Services Review 22 (winter 1994):1728.

2. Anne Lipow, "In your face' reference service," Library Journal 124 (August 1999): 50-2; Anne Lipow and Gail Schlachter, "Thinking out loud: Who will give reference service in the digital environment?" Reference \& User Services Quarterly 37 (winter 1997): 125-35.

3. Bonnie A. Nardi, "Keynote address in the Great Hall of the Library of Congress: Information ecologies," Reference Service in a Digital Age. Available online at http://cweb. loc.gov/rr/digiref/nardi.html. 